This article was downloaded by: [Memorial University of Newfoundland]

On: 27 January 2015, At: 00:23

Publisher: Routledge

Informa Ltd Registered in England and Wales Registered Number: 1072954

Registered office: Mortimer House, 37-41 Mortimer Street, London W1T

3J H, UK

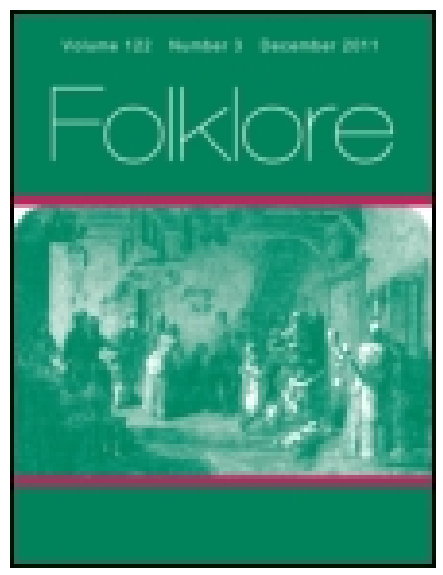

\title{
Folklore
}

Publication details, including instructions for authors and subscription information:

http:// www. tandfonline.com/loi/ rfol20

\section{Tibetan Charms.}

A. R. Wright

Published online: 06 Feb 2012.

To cite this article: A. R. Wright (1904) Tibetan Charms., Folklore, 15:1, 95-95, DOI: 10.1080/ 0015587X. 1904.9719388

To link to this article: http:// dx. doi. org/ 10.1080/0015587X.1904.9719388

\section{PLEASE SCROLL DOWN FOR ARTICLE}

Taylor \& Francis makes every effort to ensure the accuracy of all the information (the "Content") contained in the publications on our platform. However, Taylor \& Francis, our agents, and our licensors make no representations or warranties whatsoever as to the accuracy, completeness, or suitability for any purpose of the Content. Any opinions and views expressed in this publication are the opinions and views of the authors, and are not the views of or endorsed by Taylor \& Francis. The accuracy of the Content should not be relied upon and should be independently verified with primary sources of information. Taylor and Francis shall not be liable for any losses, actions, claims, proceedings, demands, costs, expenses, damages, and other liabilities whatsoever or howsoever caused arising directly or indirectly in connection with, in relation to or arising out of the use of the Content.

This article may be used for research, teaching, and private study purposes. Any substantial or systematic reproduction, redistribution, reselling, loan, sub-licensing, systematic supply, or distribution in any form to anyone is 
expressly forbidden. Terms $\&$ Conditions of access and use can be found at http://www.tandfonline.com/page/terms-and-conditions 


\section{Tibetan Charms.}

Exhibited at Meeting, 18th November, 1903. (See Plate II. and p. I.)

I. Tibetan phur-bu, or exorcist's dagger, for stabbing demons. The central part represents a thunderbolt, and the upper end the four heads (one being a horse's) of the fiend Tamdin.

2. Tibetan ga-u, or charm-box, studded with turquoises and holding four rolls of charms (4) and a fifth roll (5) bound, with silk of three colours and having attached to it some fragments from the robe of a lama or of a sacred image.

3. Metal hand: Hebrew charm against the evil eye, inscribed with the blessing of Joseph (Genesis xlix. 22-26).

6 and 7 . Medizval bronze amulet cases, one book-shaped, the other heart-shaped.

A. R. Wright.

Some Superstitions of the Fireshire Fisher-Folk.

IN Miss Morag Cameron's very interesting notes on "Highland Fisher-Folk and their Superstitions" in September issue of FolkLore (vol. xiv., p. 300), mention is made of the fact that most of the superstitions noted were also current on the Fifeshire coast. It struck me that it might be interesting to try to trace how far this is still the case, as one might reasonably expect that the "Fifers," being nearer the larger centres of town life, would lose their old beliefs more readily than their northern brethren.

Mining and fishing go largely together on some parts of our county's coast line, the miner taking the fishing season as a beneficial change from his work below ground, while the fisher does not now despise the "good money" that may be gained in the pit at such time as the harvest of the sea is not available. Irence, as well as the purely fishing and purely mining classes, we have also a mining-fishing class largely imbued with the curious beliefs of both. And yet the miner regards the fisher 